\title{
People and Blackbuck: Current Management Challenges and Opportunities'
}

\author{
Shiv Raj Bhatta²
}

\begin{abstract}
Blackbuck is one of the most magnificent animals living in close proximity to human settlement. The last surviving population of blackbuck in Nepal is found at Khairapur of Bardia District in west Nepal. The problem of land and management responsibility has been a issue for more than last 3 decade. The current issues of the management are related to: Policy, legal and institutional, habitat management, database and research and the livelihood of the neighboring communities has been briefly presented.
\end{abstract}

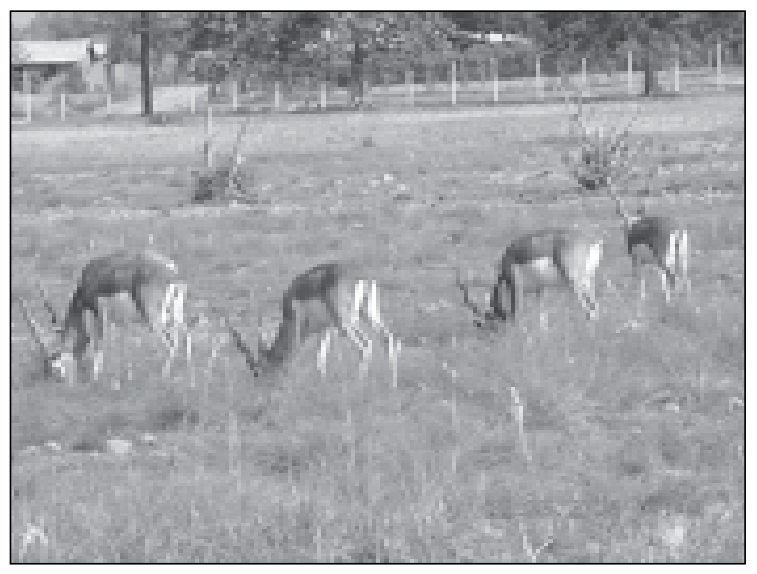

Photo Source: S.R. Bhatta

A draft 5 year action plan has been prepared by the Department to address these issues and ensure the long-term survival of the last remaining population of blackbuck in Nepal. This new model of community participation proposed for conservation and management of the area and this protected species can be taken as an opportunity for conservation. Though the area has been encroached by some illegal settlers, long-term survival of this endangered species in the middle of village without community participation is impossible.

Key Words: Blackbuck, Protected mammal, Habitat management, Crop damage, Conservation committee.

\section{Introduction}

The Blackbuck (Antelope cervicapra cervicapra), locally known as Krishnasar, is one of the 27 protected mammals of Nepal. The Blackbuck was once a common animal throughout the Indian sub-continent from Punjab to Uttar Pradesh of India and from Nepal to Bangladesh. This is one of the four blackbuck sub-species found today (Antelope cervicapra centralis in Central India, Antelope cervicapra rajputani in Rajasthan and Punjab of India, Antelope cervicapra rupicapra in South India and Antelope cervicapra cervicapra in Uttar Pradesh).

\footnotetext{
1 This article is primarily based on the proposed Blackbuck Conservation Action Plan of DNPWC

2 Department of National Parks and Wildlife Conservation, Babarmahal, Kathmandu, Nepal, shivbhatta@hotmail.com
} 
Today the remaining population of blackbuck in Nepal is at Khairapur of Bardia district. Khairapur is $6 \mathrm{~km}$. north of Gularia, the District Headquarters of Bardia and $36 \mathrm{~km}$. south of Bardia National Park. There has been continuous joint effort by the Department of Forests (DoF) and Department of National Parks and Wildlife Conservation (DNPWC) for blackbuck conservation through its field offices Bardia National Park (BNP) and District Forest Office (DFO) Gularia, in partnership with other organizations since last three decades.

Though blackbucks in Nepal survived from the verge of extinction due to conservation efforts in the last 3 decades, there are still several conservation and management issues that need to be addressed.

\section{Population Trend}

The population trend of blackbuck is given in the figure (figure 1). The status of blackbuck in the year 1975 was just 9 individuals. The population rose to 177 in 1987. It fell down to 101 in 1996 and 50 in the year 1999. Protection provided during the 1970s and 1980s had resulted in the increase of the antelope population. Anthropogenic activities (encroachment of the area, clear fell of

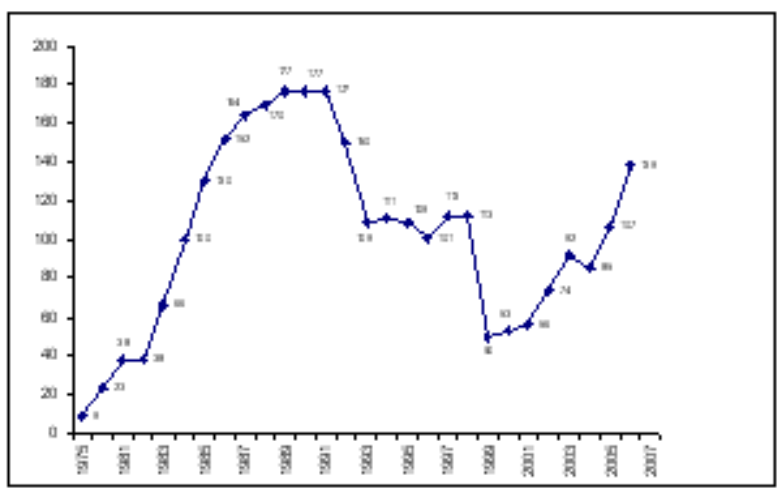

Figure 1: Population trend of blackbuck bushes, over grazing by livestock, use of stray dogs to chase blackbuck) were the main reasons for the decline in blackbuck population. Concerted effort to protect the habitat has resulted in the increase of blackbuck population once again. The current population status estimated by a study team is projected in the figure (figure 1).

Government of Nepal through Bardia National Park procured private land for the blackbuck investing Rs. 1,80,00,000 during 1995-1997. The extension of habitat by procurement of private land and other habitat management activities have improved the status of blackbuck population once again. The recent population is 184 individuals. The sudden decline in blackbuck population in 1999 was largely due to dispersal of 39 individuals on the Indian side.

\section{Current Management Challenges}

\section{Land related issues}

Originally a total of 488 hectare of land was proposed as Blackbuck Conservation Area (BCA). The idea then was to resettle the local people elsewhere and declare it as a conservation area. Now, a total of 1695 ha. (527 core blackbuck habitat and 1168 surrounding agricultural land, settlement and community forest area) has been proposed for BCA. The new concept and the proposed additional area have encouraged local participation in sharing benefit like they do in the buffer zone of a protected area. 
In December 2006, there was encroachment in both alienable and forested land and the encroachers kept on extending their occupation every day. Approximately 300 Mukta Kamaya (freed bounded laborers) had settled in the area.

\section{Management of the area}

The Government of Nepal, Ministry of Forests and Soil Conservation (MoFSC) has principally agreed on the concept of BCA. However, this has not been formally declared in a gazette. Because of this the authority responsible for the conservation, management and law enforcement is still undecided as the area partially falls under the jurisdiction of Gularia District Forest Office and a portion of which also belongs to Bardia National Park.

There is a provision of conservation area in the National Parks and Wildlife Conservation Act (NPWC Act 2029). Based on this, the area can be handed over to NGOs or CBOs for management. There is a provision for deputing of Government authority for law enforcement and technical assistance as per the requirement of the area. This has been in practice in Annapurna Conservation Area (ACA) and Kanchanjunga Conservation Area (KCA).

\section{Species Conservation (habitat management, database and research)}

Though there has been an effort to manage invasive species the problem still exists.

Tall grass is not a preferable blackbuck habitat therefore the grassland has to be maintained at a required level of short grass with preferred species composition.

Bayar bush (Zizyphus species) is a good hiding place for fawns and it protects them from predators. But the thickets are cleared completely. Thickets of ziziphus (Bayar) which are safe for fawns have been cleared completely.

The proposed area for BCA is over grazed by livestock and open lands need to be rehabilitated. The total livestock grazed in the area were 811 (671 cattle, 108 buffalo and 32 goat) in the year 1988. The number increased to $1100-1200$ in 1994 . Today above 500 livestock graze the area each day.

The protection of the community forest of the area has replaced grassland, creating suitable habitat for the predators, mainly hyena (Hyana hyena), leopard and Jungle cats (Falis chaus).

The data base on blackbuck needs to be improved and systematized. Though several studies have been conducted in the past impact studies (impact of livestock grazing, grass cutting and growing agricultural crops in the habitat area) are essential. The population has increased from only nine individuals including three males to the present size. In-breeding and the genetic variability needs to be assessed. A genetic study of this population is of high priority. The ecological aspects also need to be understood for the effective management of this species. The data base should provide information on the population dynamics, impact of raising agricultural crop in core habitat, livestock grazing, grass cutting other management interventions and the human-wildlife aspects. 


\section{Sustainable livelihood (blackbuck-human relationship)}

Road in the middle of blackbuck habitat: A road to Turantapur, Panditpur and Salarpur cuts through the blackbuck habitat. The study carried by Khanal in 2000 shows, in $12^{\text {th }}$ January 2000, 415 people, 5 motorbikes and 12 bull carts traveled from the area. Currently more than 500 people move through the road. Over 100 livestock graze in the habitat. Around 100 local people come there to cut grass every day in winter. The number reaches 500 in summer.

This issue was discussed thoroughly with the local people of the area. They have proposed for the construction of an alternate road for them along the fence on the south-west of the boundary, and have agreed not to use the road passing through the middle of the blackbuck habitat.

Crop damage by blackbuck is one of the major causes of conflict. Each year some people have to bear significant loss caused by these animals. Some 55\% of the people of adjoining villages (Salapur, Pataha, Bhariya Gown and Kamaiyamukti area) reported crop damage by blackbuck in the surrounding. Wheat, maize, lintels are the major crops foraged by the animal. Locals of Salapur, Pataha, Bhariyagown and Kamaiyamukti area suffer much from crop raiding by the animals. Stray dogs killed 9 blackbucks during 1997-2000. A total of 342 dogs were killed in 6 year 1993-1999.

\section{Proposed Programs to Address These Issues}

\section{Policy, legal and institutional}

1. Option A. Form a commission and resettle people elsewhere who are presently occupying the blackbuck habitat

Option B. Form an authorized local-level committee, identify households that must be given land and resettle them along the boundary of community forest and remove all other from the area.

2. Declare the area as BCA

3. Assign management authority

\section{Species conservation (habitat management, database and research)}

\section{- Habitat management}

1. Divide blackbuck habitat in the following 4 blocks and manage them accordingly. The proposed block division is based on the current land use pattern (use of the area by local people and blackbuck). It has also been taken as a pilot program to regulate and monitor management interventions.

Block A: Allow grazing and grass cutting

Block B: Allow grazing, grass cutting and practice seasonal agriculture preferred by blackbuck

Block C: Allow grass cutting only and develop Bayar (Zizyphus) bushes by planting seedlings

Block D: Allow grazing and grass cutting only during monsoon 
2. Create alternate habitat and population of blackbuck

3. Protect blackbuck habitat through joint management of community and the Government

\section{Data-base and research}

\section{- Programs}

1. DNPWC, academic institutions and conservation partners develop a mechanism to jointly update database and conduct research in the area.

2. Translocation of blackbuck

\section{Sustainable livelihoods}

\section{- Programs}

1. Provide alternative access road to the local community

2. Allow controlled resource use

3. Minimize crop damage

4. Promotion of Eco-tourism

5. Assist local community by providing options for alternative livelihood

\section{Proposed Organizational Structure}

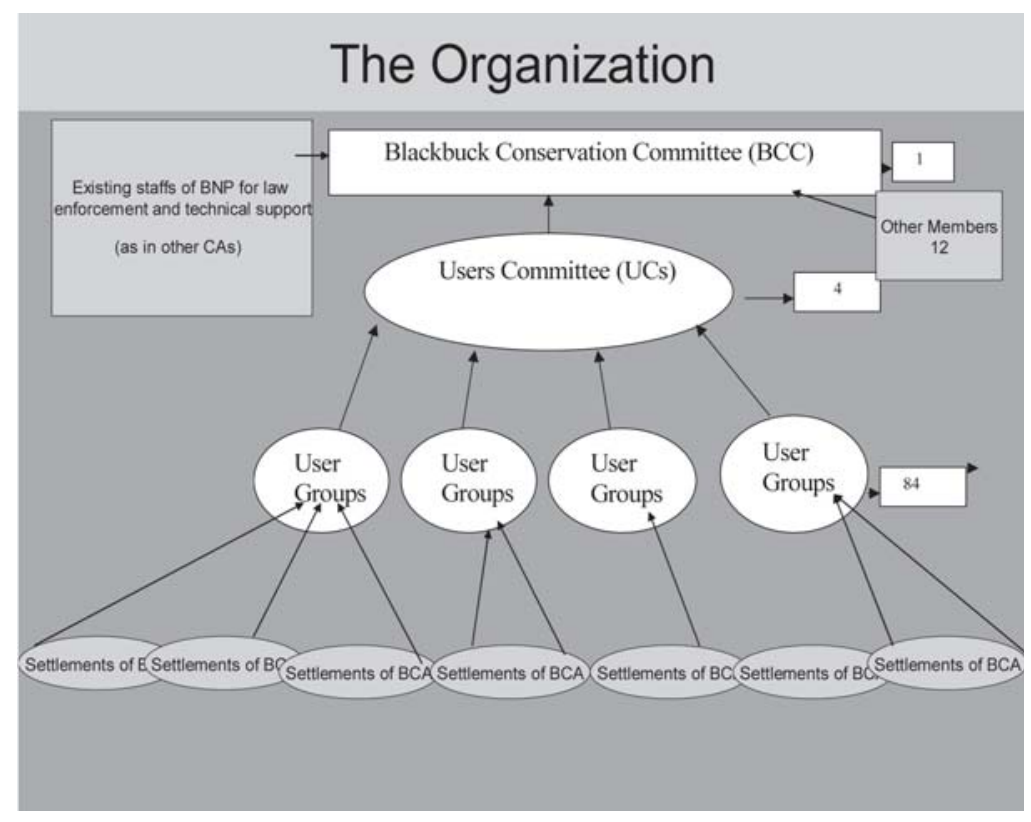

The Blackbuck Conservation Committee (BCC) will be responsible for planning, implementation and monitoring of the activities. The protection activities and daily administration will be jointly carried out by BCC and the BNP staff deputed there. The law enforcement has to be carried out by BNP. The details of the duties and responsibilities will have to be included in the BCA regulation. 